\title{
Forest conservation index and historical evolution in a coastal region: The São Sebastião Island, São Paulo, Brazil
}

\author{
Índice de conservación de bosques y evolución histórica en una región costera: Isla São Sebastião, \\ São Paulo, Brasil
}

\author{
Vivian Hackbart a *, Guilherme Lima ${ }^{\text {a }}$, Rozely Santos ${ }^{\text {a }}$ \\ *Corresponding author: ${ }^{\text {a }}$ State University of Campinas, Environmental Planning Laboratory, Cidade Universitária, PO Box 6021, \\ ZC 13.083-970, Campinas SP, Brazil, vhackbart@gmail.com
}

\author{
SUMMARY
}

The aim of this study is to identify the current conservation status of five forested watersheds which have been under different human pressures throughout history of São Sebastião Island to assess relations between pressures which have occurred in the past and the current environmental quality. Through maps of land use, landscape metrics, and the development of a forest conservation index, it was possible to identify in watersheds the greater landscape fragmentation, implications on quantity and quality of available habitat, and effects of boundaries.

Key words: landscape change, landscape metrics, indexes.

\section{RESUMEN}

El objetivo de este estudio es identificar el estado de conservación de cinco cuencas en diferentes fases evolutivas en la isla de São Sebastião (SP) de manera que se pueda evaluar las relaciones entre las presiones pretéritas y la calidad del medio ambiente actual. A través de mapas de uso del suelo, las medidas del paisaje y el desarrollo de un índice de conservación de bosques fue posible identificar en las cuencas la mayor fragmentación del paisaje, las implicaciones sobre cantidad y calidad del hábitat disponible, y los efectos de las fronteras.

Palabras clave: cambios del paisaje, métricas del paisaje, índices.

\section{INTRODUCTION}

Many habitats have been fragmented by human activities, in order to use natural resources (Botequilha-Leitão et al. 2006); creating mosaics that result in losses of large continuous forest areas (Lang and Blascheke 2009). The extent of forest loss is highly dependent on human pressures throughout the landscape's history, and it varies with different territories (Bertolo et al. 2010). The specific changes in each segment of the territory create a structural heterogeneity in the landscape, which can be evaluated by composition and configuration metrics and forest conservation indexes. The information provided by metric and index are related to ecosystem structure's complexity (Peng et al. 2010), function, and composition of the ecological system, features including conservation state of forests and human interference in landscape (Bertolo et al. 2012). In this context, the aim of this study is to identify the current conservation status of five forested watersheds which have been under different human pressures throughout history of St. Sebastian Island (evolution phases).

\section{METHODS}

The mapping of São Sebastião Island (SP), the selection of watersheds, and their segmentation into two zones are shown in figure 1.

Five watersheds were selected representing different evolution phases described by Bertolo et al. (2010): preservation, conservation, regeneration, exploitation, and urbanization. Because of the occurrence of different historical land uses (Lima 2011), the watersheds were segmented in two zones both above and below (A and $\mathrm{B}$ ) 100 m altitude.

Several authors (Botequilha-Leitão et al. 2006, Lang and Blascheke 2009) suggest that one way to understand the condition of the landscape is through of indexes and metrics that summarize mathematically maximum information. In this direction, we proposed an index involving different successional stages of forest as a good indicator of the conservation state. The forest conservation index (IC) was developed for zones A and B of the watersheds and their standard values (equation 1) from the amount of dense ombrophilous forest (i) at advanced succession stages 
Images SPOT 5 (2009)

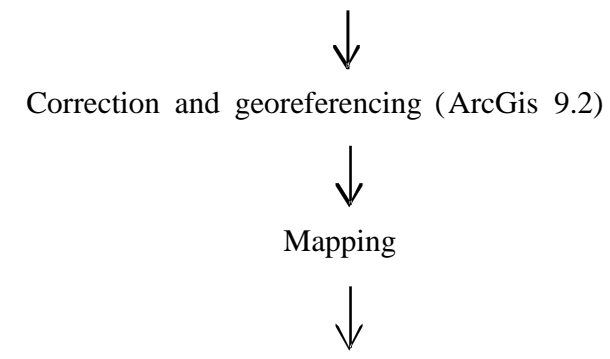

Selection of watersheds in different evolutive phases (B ertolo etal. 2010)

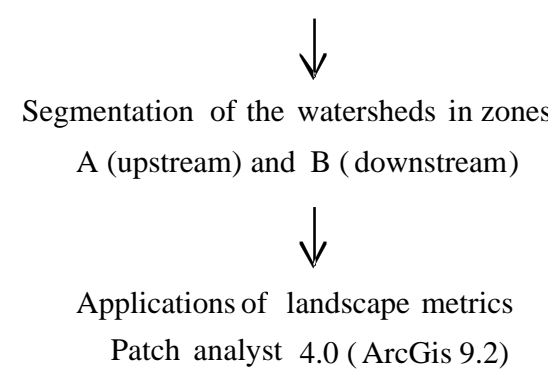

Figure 1. Flowchart of the materials and methods used. Diagrama de flujo de los materiales y métodos utilizados.

(FODm/a) (ii) at intermediate succession stages and remnants (FODi,r) and (iii) at initial (FODp). The quantities of forest were weighted in favour of the best succession stage and summed using equation 2 . The equations 1 and 2 were developed for this investigation and the weights were based on Tabarelli and Mantovani (1999).

$$
\mathrm{VPi}=\frac{\mathrm{V} i j}{\operatorname{Vimax}}
$$

Where,

VPi: standard value of metric $i$.

Vij: metric's value $i$ for watershed $j$.

Vimax: highest metric's value $i$ in all watersheds.

$$
I C j=(\text { FOD maj } \times 1)+(\text { FODIrj } \times 0.6)+(\text { FOD pi } \times 0.3)
$$

Where,

ICj: forest conservation index of watershed $j$.

FODmaj: FODm/a of watershed $j$.

FODIrj: FODi,r of watershed $j$.

FODpj: FODp of watershed $j$.

Four metrics widely used in academic researches (Geri et al. 2010) to investigate landscape fragmentation by composition and configuration were selected: mean patch size (MPS), mean patch edges (MPE), number of patches (NumP); class area proportion (CAP).

To verify reasonable relationship between fragmentation effects and quality of forest was used regression analyses performed between: (a) between forest conservation index of watershed and standardized metric's results; and (b) mapped class area proportion for dominant class (CAP) in each evolutive phase and zones A and B. $\mathrm{R}^{2}$ values $\geq 0.95$ were considered for zone A.

\section{RESULTS}

In the five watersheds studied, we have been identified 34 types of land uses and natural vegetation cover, with $60 \%$ area of Dense Ombrophilous Forest associated with different stages of regeneration and different types of land use (figure 2).

The values of $\mathrm{R}^{2}$ metrics relative to forest conservation index of watershed, the zones A and B for all watersheds showed that there was a tendency of second order of polynomial regression in both zones, but most significant to zone A (table 1). The exception was number of patches in zone B, which showed an exponential relationship with the forest conservation index of watershed.

The results showed that: (1) number of patches had a distinct behavior between zones A and B (figure 3), indicating that for $\mathrm{B}$ there were high values of number of patches and low values of forest conservation index of watershed without inflection point; (2) mean patch size showed that the greater number of patches and a larger number of small patches, decreasing the quality of the landscape due to the increase of fragmentation (figure 3); (3) mean patch edges the better state phases (preservation and conservation) showed the largest mean patch size of forest for both zones (figure 3).

The class area proportion confirmed what was expected for watersheds in opposite evolutive phases (figure 4), larger tracts of forest at the advanced succession stage for both zones in preservation phase and higher values of human interference for both zones in urbanization phase.

Table 1. Results of $\mathrm{R}^{2}$ for metrics in relation of forest conservation index.

Resultados de $\mathrm{R}^{2}$ para las métricas relativas al índice de conservación de bosques.

\begin{tabular}{lcc}
\hline \multirow{2}{*}{ Metrics } & \multicolumn{2}{c}{$\mathrm{R}^{2}$} \\
\cline { 2 - 3 } & A zone & B zone \\
\hline MPS & $0.99(\mathrm{p})$ & $0.72(\mathrm{p})$ \\
MPE & $0.99(\mathrm{p})$ & $0.75(\mathrm{p})$ \\
NumP & $0.98(\mathrm{p})$ & $0.74(\mathrm{e})$ \\
CAPd & $0.95(\mathrm{p})$ & $0.46(\mathrm{p})$ \\
\hline
\end{tabular}

MPS: mean patch size; MPE: mean patch edge; NumP: number of patches; CAPd: class area proportion dominant. (p): polynomial; (e): exponential. 


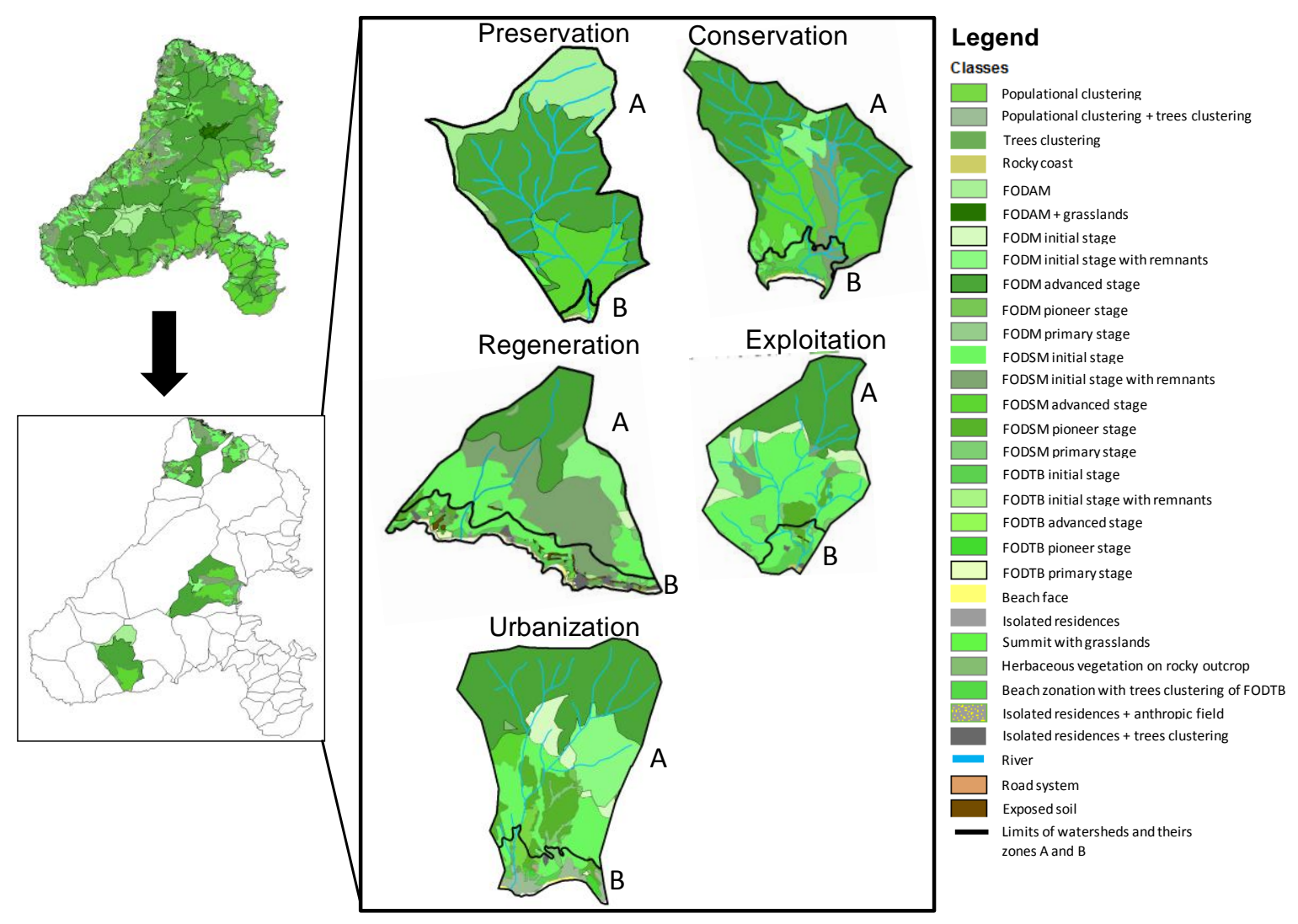

Figure 2. Types of uses and natural vegetation cover of watersheds of Ilhabela (Fundação Florestal, in press). Tipos de usos y cobertura de vegetación natural de las cuencas de Ilhabela (Fundação Florestal, in press).
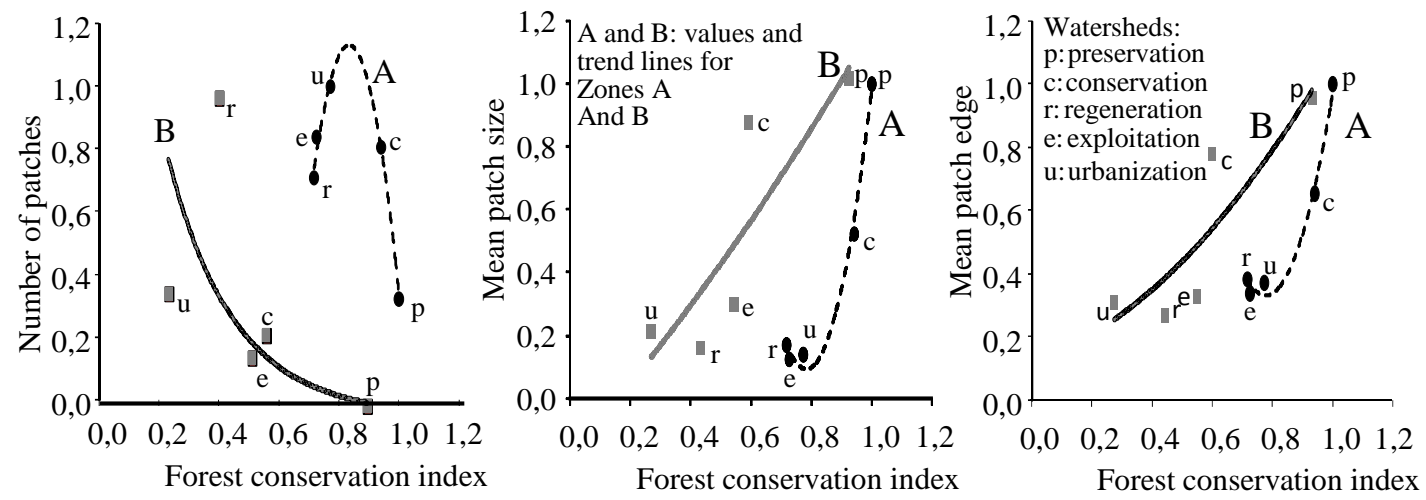

Figure 3. Relationship between forest conservation index and landscape metrics for watersheds in five evolutive phases. Relación entre el índice de conservación de bosque y las métricas de paisaje para cuencas en cinco fases evolutivas.

The forest conservation index $(\mathrm{CI})$ showed a high correlation $\left(\mathrm{R}^{2}=0.95\right)$ with the dominant classes in the A zones. For B zone, the IC exhibited a low value of $\mathrm{R}^{2}$ probably caused by high landscape fragmentation. Except for preservation's phase, the CAPD for B zone to conservation, regeneration and exploitation phases were represented by vegetation in early stages. For urbanization's phase the human interference was the dominant class (figure 5).

\section{DISCUSSION}

The mapping shows that the presence of the Ilhabela State Park (PEIB) is fundamental to keep the more advanced stages of forest succession in larger areas (figure 2), corroborating the information described by Bertolo et al. (2010).

The second order polynomial regression between most of the metrics and forest conservation index of watershed 

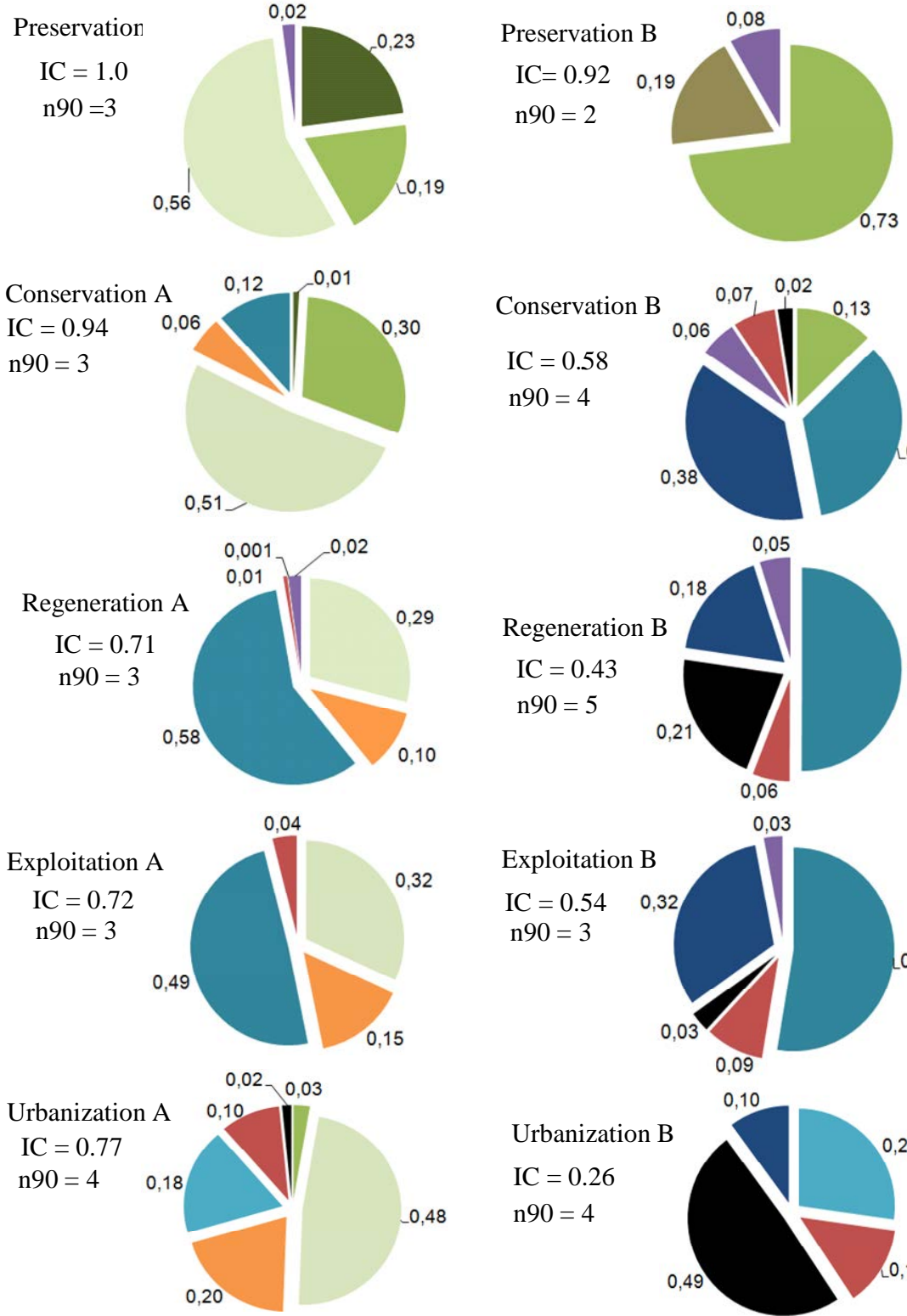
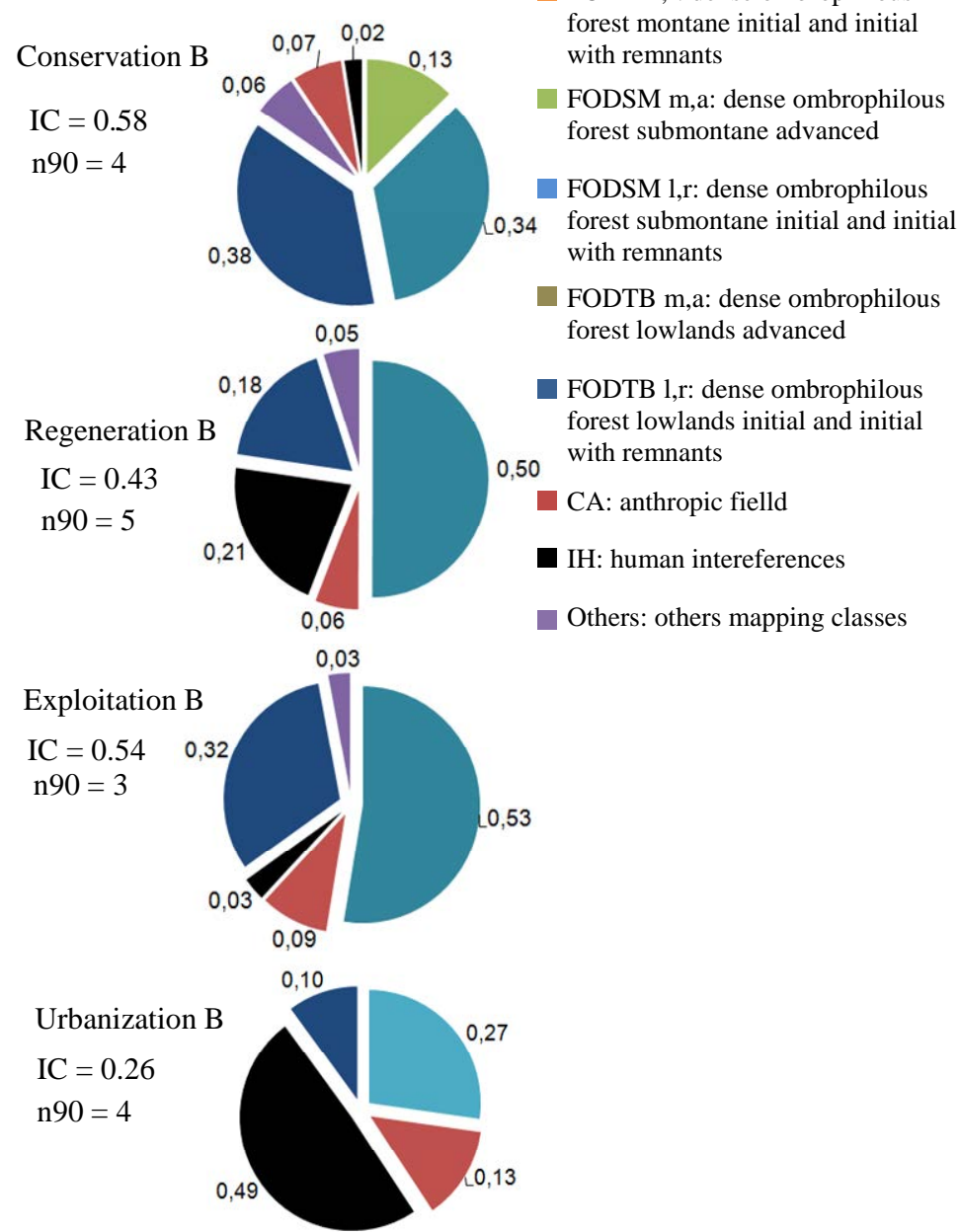

FODAM : dense ombrophilous forest of highland

FODM m,a: dense ombrophilous forest of montane advanced

FODM I,r: dense ombrophilous forest montane initial and initial

FODSM m,a: dense ombrophilous

FODSM I,r: dense ombrophilous forest submontane initial and initia with remnants

FODTB m,a: dense ombrophilous

FODTB I,r: dense ombrophilous forest lowlands initial and initial with remnants

CA : anthropic fielld

Others: others mapping classes

Figure 4. Class area proportion for zones A and B of watersheds. IC: forest conservation index; n90: number of mapped classes to cover $90 \%$ of the landscape.

Proporción de clases de áreas para las zonas A y B de las cuencas. IC: Índice de conservación de bosque; $\mathrm{n}_{90}$ : número de clases mapeadas para cubrir el $90 \%$ del paisaje.

indicates the existence of an inflection point, from which the increased quality of the forest can cause significant changes in metrics. This could indicate the existence of a critical amount of forest, on the São Sebastião Island, necessary for proper maintenance of ecological processes. This value for A and B area is in the range 618-704 ha and 63-72 respectively, about 70-80 \% of forest cover.

The regression between forest conservation index of watershed and metrics shows that there is a significant degree of fragmentation in B zones of the watersheds, and most representative in the regeneration phase, resulting in major changes in biological processes and the existence of a strong relationship between the boundaries and the general state of forest conservation.

The class area proportion - for reporting the abundance of each type of land use - is one of the simplest metrics to analyze the landscape (Botequilha-Leitão et al. 2006) when different landscapes are compared. Thus, it is observed that in relation to watersheds in phases of urbanization and regeneration, the great diversity of types of land uses is indicative of high landscape fragmentation, resulting in a wide variety of environments. This could cause losses of habitat, decreases in environmental quality, and consequent reduction in resources available for the species 


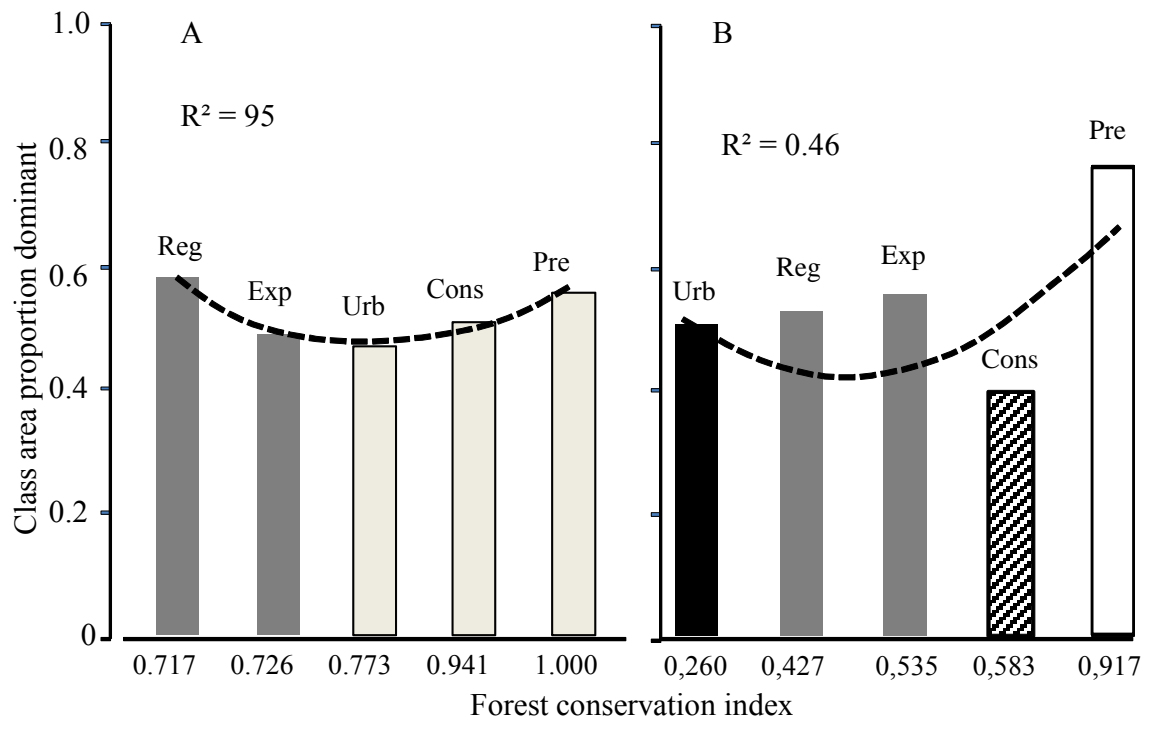

FODSM I,r : dense ombrophilousforest of montane advnitial

FODM m,a : dense ombrophilousforest of montane advanced

$\mathrm{IH}$ : human interferences

W FODTB I,r: dense ombrophilousforest lowland initial

FODSM m,a : dense ombrophilousforest submontane advanced

Pre: preservation Cons: conservation Reg: regeneration Exp: exploitation Urb: urbanization

Figure 5. Relationship between forest conservation index and the dominant class (CAP) for zones A and B of watersheds. Relaciones entre el índice de conservación de bosque y las clases dominantes (CAP) para las zonas A y B de las cuencas.

(Botequilha-Leitão et al. 2006). For the regeneration phase, the class area proportion as well as metrics reflecting a conflict with historical classification, indicating that the classification made by Bertolo et al. (2010) in this watershed should be reviewed in relation to 2009.

Despite the visible loss of watershed quality in the regeneration phase, it can be assumed that in current times, there is sufficient environmental quality for the maintenance of biodiversity, especially because of the dominance of herbaceous/shrub species. Those species are few and are fast growing between ten and thirty years (Veloso et al. 1991). Thus, although "FODSMI,r" represents the largest area in watershed, this vegetation could not reach its succession climax, making it more vulnerable to human activities and natural processes of weathering.

The forest conservation index of watershed shows a high correlation with the dominant classes determined by the class area proportion in zone A (figure 5), represented by the forest in advanced stages of succession, especially in the urbanization phase. This phase presents a greater amount of vegetation with a better quality when compared with the regeneration and exploitation phases, despite being more fragmented in zone $\mathrm{A}$ than the other two watersheds.

For zone $\mathrm{B}$ (figure $5 \mathrm{~B}$ ), the low value of $\mathrm{R}^{2}$ for the forest conservation index of watershed could be due to high frag- mentation of the landscape and a high variety of mapped classes. In this zone, the class area proportion for conservation, regeneration, and exploitation phases are represented by the vegetation in the early stages while for the urbanization phase, the human interference is the dominant class.

\section{CONCLUSIONS}

The sum of information between the mean patch edges, mean patch size, class area proportion and number of patches metrics identifies the increase of fragmentation caused by human actions between watersheds at different stages of human influences throughout history. This can be observed mainly below $100 \mathrm{~m}$ altitude, with an emphasis on the regeneration phase.

The data indicates that there is a forest critical amount for São Sebastião Island that may vary from 618-704 ha and 63-72 ha (around 70-80 \%), respectively, A and B zones. This amount is necessary for proper maintenance of ecological processes and ecosystem services.

\section{ACKNOWLEDGMENTS}

This research was funded by CAPES (Coordination for the Improvement of Higher Level -or Education- 
Personnel) and CNPq (National Council for Scientific and Technological Development). We would also like to thank for the Foundation Forest-Brazil, the administration of Ilhabela State Park.

\section{REFERENCES}

Bertolo LS, GT Lima, RF Santos. 2010. Spatiotemporal change indexes to identify the historical evolution in a coastal region - case study: São Sebastião Island- SP. Brazilian Journal of Oceanograph 58: 37-47.

Bertolo LS, GT Lima, RF Santos. 2012. Identifying change trajectories and evolutive phases on coastal landscapes. Case study: São Sebastião Island- SP. Landscape and Urban Planning (106): 115-123.

Botequilha-Leitão A, J Miller, J Ahern, K McGarigal. 2006. Measuring landscapes: A planner's handbook. Washington D.C., USA. Island Press. 245 p.

Geri F, D Rocchini, A Chiaricci. 2010. Landscape metrics and topographical determinants of large-scale forest dynamics in a Mediterranean landscape. Landscape and Urban Planning (95): 46-53.

Lang S, T Blascheke. 2009. Landscape analysis with GIS. São Paulo: Oficina de Textos. 420 p.

Lima GT. 2011. Methodology for driving forces and change vectors evaluation in the determination of ecossystem services. PhD. Thesis. Campinas, Brasil. Universidade Estadual de Campinas UNICAMP, Faculdade de Engenharia Civil, Arquitetura e Urbanismo, FEC. 132 p.

Peng J, Y Wang, Y Zhang, J Wu, W Li, Y Li. 2010. Evaluating the effectiveness of landscape metrics in quantifying spatial patterns. Ecological Indicators 10: 217-223.

Tabarelli M, W Mantovani. 1999. Regeneration of a neotropical montane forest following slash-and-burn (São Paulo-Brasil). Revista Brasileira de Biologia 59(2): 239-250.

Veloso HP, AL Rangel Filho, JC Lima. 1991. Brazilian vegetation classification, adapted to a universal system. Rio de Janeiro, Brasil. Fundação Instituto Brasileiro de Geografia e Estatística - IBGE. 123 p. 